Abstracta Iranica Abstracta Iranica

Revue bibliographique pour le domaine irano-aryen

Volume 27 | 2006

Comptes rendus des publications de 2004

\title{
Lire Lolita à Téhéran. Récit. Trad. par Marie-Hélène Dumas, Paris, Plon, 2004 [= Reading Lolita in Tehran, New York, 2003], 393 p.
}

\section{Yann Richard}

\section{(2) OpenEdition}

1 Journals

\section{Édition électronique}

URL : http://journals.openedition.org/abstractairanica/6056

DOI : 10.4000/abstractairanica.6056

ISSN : 1961-960X

Éditeur :

CNRS (UMR 7528 Mondes iraniens et indiens), Éditions de l'IFRI

\section{Édition imprimée}

Date de publication : 15 mai 2006

ISSN : 0240-8910

Référence électronique

Yann Richard, "Lire Lolita à Téhéran. Récit. Trad. par Marie-Hélène Dumas, Paris, Plon, 2004 [= Reading Lolita in Tehran, New York, 2003], 393 p. », Abstracta Iranica [En ligne], Volume 27 | 2006, document 218, mis en ligne le 02 janvier 2007, consulté le 25 septembre 2020. URL : http://journals.openedition.org/ abstractairanica/6056 ; DOI : https://doi.org/10.4000/abstractairanica.6056

Ce document a été généré automatiquement le 25 septembre 2020.

Tous droits réservés 
Lire Lolita à Téhéran. Récit. Trad. par Marie-Hélène Dumas, Paris, Plon, 2004 [= Reading Lolita in Tehran, New York, 2003], 393 p.

Yann Richard 
«Récit», c'est-à-dire ni étude systématique, ni reportage, ni enquête, ni analyse ordonnée, ni journal intime. C'est effectivement une expérience littéraire originale qui consiste à raconter une lecture collective dans un contexte particulier. L'A., professeur de littérature comparée à l'Université de Téhéran au moment de la révolution, s'est trouvée confrontée, au moment de la "révolution culturelle » et de la fermeture des universités, à la soif de lecture signifiante de la part de quelques uns de ses étudiants. De quelques unes faut-il dire, puisque c'est finalement, pour des raisons pratiques (mais non innocentes), entre femmes qu'elles ont mené les lectures actives de plusieurs grandes œuvres provocantes de la littérature occidentale, notamment Lolita de Nabokov et Gatsby le Magnifique de Scott Fitzgerald: un choix qui les mettait bien évidemment en marge de toute idéologie. Rythmée par de petits événements familiaux ou personnels et par des anecdotes symboliques liées à la Révolution, ou par les mesures plus ou moins contraignantes des autorités universitaires et civiles... la lecture et la vie s'entrecroisent. L'analyse de la relation au pouvoir de ces jeunes femmes confrontées aux interdits et à la perversion, entre littérature et politique, est saisissante. Elle aboutit à cette clé, donnée p. 371 par l'A., qui intériorise cette relation au texte: "Vivre dans la République islamique, c'est comme coucher avec un homme qui te dégoûte. "Bien sûr cette tranche de vie intellectuelle, vécue sur le mode obsidionnal par des femmes que tout détournait de l'engagement révolutionnaire, est d'une signification limitée, marquée par l'origine bourgeoise et occidentalisée des protagonistes, mais cependant représentative d'un certain féminisme tourné vers la modernité, face à une histoire qui l'avait prise de court.

\section{INDEX}

Thèmes : 4.3. Histoire de l'Iran moderne (à partir de 1905)

\section{AUTEURS}

YANN RICHARD

Sorbonne Nouvelle - Paris III 